\title{
THE MASTERY OF ENGLISH TOURISM TERMS \\ ACHIEVED BY THE THIRD YEAR STUDENTS OF SMKP SANDHY PUTRA MAKASSAR
}

\author{
Helmi Syukur \\ UIN Alauddin Makassar \\ shelmysyukur@gmail.com
}

\begin{abstract}
This research aimed at identifying the student's achievement in mastering English Tourism terms and factors that influence their achievement the of English tourism Terms at STKIP Sandhy putra 1 Makassar. The data collected were multiple choice test and questionnaire. In doing this research, the writer used descriptive quantitative with total sampling. The subject of this research consist of the third year students of SMKP Sandhy Putra 1 Makassar who enrolled in academic. The result of the research showed that out from 60 sample of both departments, hotel affairs accomodation got 7,3 scores and categorized as fairly good, while Tourism Plan department got 8,1 scores and they categorized as good. The research concluded that the third grade students of SMKP Sandhy Putra 1 Makassar generally were good in mastering English Tourism Terms. This was supported by the students' high motivation, supporting facilities and continuity practising and assignment giving by their teacher.
\end{abstract}

Keywords: English Tourism Terms

\begin{abstract}
Abstrak
Penelitian ini bertujuan untuk mengetahui prestasi belajar siswa dalam menguasai istilah dan faktor Pariwisata Inggris yang mempengaruhi prestasi belajar mereka terhadap Syarat Pariwisata Inggris di STKIP Sandhy putra 1 Makassar. Data yang terkumpul adalah tes pilihan berganda dan kuesioner. Dalam melakukan penelitian ini, penulis menggunakan deskriptif kuantitatif dengan total sampling. Subyek penelitian ini terdiri dari siswa kelas tiga SMKP Sandhy Putra 1 Makassar yang terdaftar di bidang akademik. Hasil penelitian menunjukkan bahwa dari 60 sampel dari kedua departemen, akomodasi urusan hotel mendapat nilai 7,3 dan dikategorikan cukup baik, sedangkan Dinas Pariwisata mendapat 8,1 nilai dan dikategorikan baik. Hasil penelitian menyimpulkan bahwa siswa kelas tiga SMKP Sandhy Putra 1 Makassar umumnya ahli dalam menguasai Persyaratan Pariwisata Bahasa Inggris. Hal ini didukung oleh motivasi, fasilitas pendukung dan kesinambungan pengajaran dan pemberian pelajaran oleh guru mereka.
\end{abstract}

Kata Kunci: Istilah Pariwisata dalam Bahasa Inggris

\section{INTRODUCTION}

Realizing the importance of English nowadays, Indonesian students have studied it for various purposes, especially for the people of getting science and adopting advanced technology for our national development. The English teaching it self has developed, changed, and been innovated. As the response of the high demand for 
English, English for specific purposes (ESP) which is classified into English for Academic Purposes (EAP) and English for Occupied Purposes (EOP) has emerged. In the globalization era, English becoming much more important meaning of communication in the world. It is considering as an International language and the most favourite language in the tourism world.

Indonesian is known as the beautiful country to visit by tourist. Many people from all over the world visit Indonesia in order to enjoy the natural beauty of Indonesian flora, fauna and ancient tradition. The region unique culture, mystical ways of life and ethnic natural beauty make a notable addition for one's travel experience.

Accommodation facilities, such as hotel, and the tourism facilities have been built to support other effort by government that is development human resources. As we know that tourism sector will be more valuable if it is supported by skilful human resource. That's way the government felt necessary to establish formal and nonformal education. As it is stimulated in GBHN 1989/MPR.R1 No-Il:

"Dalam rangka pembangunan kepariwisataan, perlu ditingkatkan langkahlangkah terarah dan terpadu dalam pembangnnan objek-objek wisata serta kegiatan promosi dan pemasarannya baik di dalam maupun di luar negeri. Selanjutnya perlu ditingkatkan pendidikan pelatihan kepariwisataan, penyediaan sarana dan prasarana, mutu dan kelancaran pelayanan serta penyelenggaraan pariwisata". (Ningsih, 1999:4)

Tourism Vocational High School is one of the vocational school which is expected to anticipate the problem relate to tourism field. This institution is expected to produce graduate which are able to handle the tourism industry's problem.

To be qualified graduates, there are two factors that should be taken into consideration. First, the ability of speaking foreign language particularly the English language, which covets general English, used in conversation and the mastery of specific English terms used for the object of tourism, concerning archaeology, history, ethnography and the natural panorama. Second, they ought to have background knowledge about the culture and the history of the native people, as well as geography of the country.

Different from another ordinary high school in this country, the students of tourism

school are expected to be able to use English commonly and to be able to use English tourism terms as suggested in GBPP particularly. Some activities usually carried out to improve the English ability to use the tourism terms the local practice of a profession and out of practice of profession (prakerin) under the teacher guidance which aim at achieving the target as suggested in the curriculum.

Basically, English for tourism terms is quite different from general English. People sometimes have difficulties to comprehend English tourism terms especially the tourism terms, because some of the tourism terms have different meaning from general English (Hasan,1989:80) stated that in tourism language there are some words 
or terms and abbreviations are rarely found or different meaning from those in general English.

Based on the statement above, the writer has motivation to present this research entitled: "The Mastery of English Tourism Terms Achieved by the

Third Year Students of SMKP Sandhy Putra I Makassar".

\section{LITERATURE REVIEW}

\section{The Concept of Tourism}

The concept of tourism was first formulated in the period between the Second World War and the definition put forward by the Swiss professor Hunzieker and Craft Subsequently adopted by the International Association of Scientific Exports in Tourism (IASET).

Tourism is the sum of phenomenon and relationship aging from the travel and stay of none resident in so far as they do lead to permanent residents and are not connected with any earns activity. Whereas Burkart (1981:43) denotes tourism shortterm movement of people to destination outside the place where they normally live and work and their activities during they stay at those destinations.

Both of definition above refers to the characteristic of tourism namely:

a. Tourism arises from a movement of people to and their stay in vanous destinations.

b. There are two elements in all tourism; the journey to destination and they stay including activities at the destination.

c. The journey and the stay take place outside the normal place of residence and work, so that tourist gives rise to activities, which are distinct from those of the residence and working populations of the places, through which tourist travel and which they stay.

d. Movement to destination is a temporary short-term character, with iteration to return within a few days' week and months.

e. Destination is visited for purposed whether that taking up permanent residence or employ meted from within the place visited.

Tourism is a leisure activity, which involved a discretionary use of time and money, and recreation is often the main purpose for participation in tourism. But this is no reason for restricts the total concept in this way and this essential characteristic of tourism can be best interpreted to embrace a wider concept.

Tourism denotes the incidence of mobile population some travellers who are strangers to the places they visit and where they represent a distinct element from the resident and working population. All tourism includes some travel but not all travel in tourism $(1981 \cdot 47)$.

In endeavouring to define tourism it is helpful some of definition in the following:

a. Tour is a journey in which are 3 reforms to the starting points; a circulated 4 trip equally for business, pleasure or education during which various places are visited and for which an itinerary is often planed. 
b. Tourist is one to make a tour, one that travels from place LO place for pleasure of culture.

c. Tourism is the practice of touring, the guidance or management of tourist as business governmental function, provision of itineraries guidance and accommodation of tourist.

The New Oxford Dictionary (Hornby, 1995:1765) defines:

a. Tour is a journey thus part to country from place to place.

b. Tourism is organized touring, accommodation and entertainment of tourist as industry.

c. Tourist is people who make a tour, person who travel for pleasure.

Matheson and Wall in Ins keep (1991:23) define tourism as the temporary movement to destination outside the normal home work place, they activities undertaken during the stay and the facilities created to cater for the need of tourist. The United Nation definition of tourism adapted by the United Nation Conference on Travel and Tourism, 1968 other than that in which he has usual places occupation renumbered from within the country visited, (Cropper, 1993:15).

Matheson and Wall in Kesrul (2003:12) stated that tourist. Opposed to a day visitor, is someone who spending at least 24 hours (that is overnight) away from home. There is no generally accepted maximum time limit for a tourist visited. It is normally accepted that a tourist is away from home for a relatively short period. Similarly, the money spend on the trip by a tourist would be carried out at home and not at the place visited. Prievrat in Davis (1986: 110) states that visitors become a tourist when they felt they are engaging on tourism, therefore on occasions, business, visitor could become true holyday tourist while taking a part in recreation activities at destination during a period of time when they felt at leisure.

Based on the definition above the writer formulates the definition of tourism as the circulation trip outside residence to various places for temporary (at least 24 hours) a period time of leisure.

B. Technical Definition of Tourism

The broad concept outline above, tourism is variously interpreted for particular purposes and there are at least three particular aspects which need to be defined.

The first is the purpose of travel or visit which express particular motivation. According to MacIntosh (2005) the motivation of tour is categories as physical, cultural, interpersonal and status and prestige motivation.

Secondly, it is usually necessary to define the three elements. The minimum and maximum period in term of length of stay at the particular destination may have to be established for a particular purpose. Thus travel or stay for a period shorter that a postulated minimum, for example less than twenty four hours, may be excluded. 
Third, a technical definition has to recognize particular situation which may obtain for particular purposes and it has to be determined whether they are or not regarded as tourism for examples sea cruise and transit traffic.

C. The Development of Tourism

In our country, tourism has advance and grown to become an independent Industry for the last ten years. It has led to the advancement of every sector. Formally tourism started to be initiated by the presence of Bagian Hotel Negara and Tourism (Honet). For short in 1955, Foundation of Tourism Indonesia and PT Natour (National Hotel and Tourism Corporation Ltd) were established. These foundations were not commercial oriented. However, they were aimed at developing Indonesia Tourism. The effort makes the guiding of private business operating in fields of tourism and provided suggestions to the government (Himawati 1976:68). In 1975 Musyawarah Nasional Tourism was held in Bogor, which formed "Dewan Tourisme Indonesia". The aims of institution were to continuous the tourism business. Tourism at this time was in government status. This board was given task to spend up contact with PÂTÁ (Pasific Area Travel Association) and then carried out Intensive promotion as well as strived for the tariffs of hotel and tourism facilities. In 1988, the word stourisma" was changed into "Pariwisata" In Musyawarah Naslonal Tourism Il held in Tretes (Hlmawati, 1976:69).

In 1969, there was a new phrase tourism development In Indonesia, and furthermore the establishment of various institution in change of the tourism business both either national and regional one (Himawati, 1976:71).

In general, the terms "tourism" the "tourism industry" and "service facilities" are own of the same. It is through the service and facilities for tourism that local economies get their first impact for tourism. Accommodation, food service, etc are conspicuous business evidence of tourism development, (Bulls, 1991•.29).

In addition, the development of tourism in one of the important demands: i.e. the mastery of foreign language, such as English and others tourism languages. The mastery of English is very Important, that's way the teaching and learning of English for specific purposes is considerable required.

Further, it was clear for us that tourism is an activity complex mixture of material and psychological elements. The material ones are accommodations, transportation, the attraction and entertainment available.

The psychological factors include a wide spectrum of attitudes and expectation as mentioned earlier. Besides, the most important thin - to anticipate is domestic safety conduct guarantee (2005). What is happen in our country in the last seven years was become a national big homework to be done. Fear of terrorism is a problem that cannot be ignored. All of the citizens and the government of Indonesia must work together to solve this problem as soon as possible to prevent the loss of our country's foreign exchange sources in most.

Thousands of tourist came to Indonesia each year. They include visitors from countries as far as North America and Europe. Why do some people leave their 
hometown or countries to travel to Indonesia? Why do they willing to spend much money to travel to our country than just sitting down in front of their fire place and read some books about Indonesia's tourism?

The answer is probably because many people like to go on trips for the fun or for seeing new strange thing and Indonesia become one of the interesting places where they expect to see. Just reading a book was not enough because book cannot explain everything to them, so it is very good idea for them to Indonesia themselves. This is a beautiful country with friendly people, good music and dances, spicy food from over the islands. The entire world knows about it and become our duty to defend that good image. In short, the tourist will come, if the government and the people of Indonesia offer good things to see offer good things to enjoy and offer good safe in protection.

D. The Use of English Tourism Terms

As far, the writer thinks that to be qualified graduate, there are two important questions to be answered. The first question is "what to tell" and the second one is 'thow to tell" I he first question is concerned with the background knowledge about the object of tourism, and the second one is concerned with the ability to speak, especially English language and English tourism terms.

1. English for Hotel

Callaghan in Baker (1944:93) states that hotels are one of the most important accommodation types in tourism. Still with his statement, based on the hotel management, there are Front Office Department, Housekeeping Department, Food and Beverage Department and Food Production Department. In this case, the writer just describes two types of main departments, which deals with the field of research that is Front Office and Housekeeping Department.

The business organization concerned with travel and tourism can be classified under the following heading representing the main industrial sector.

The components of tour and travel industry are.

1. Passenger Transport (transportation department), the means by which tourist reaches their destination and has mobility on arrival passenger transport operation in a special significance for the tourist experience. Facilities likes airlines, ships, railways, bus component, car hiring, but airlines is the one of the most popular transportation for overseas package their holidays. At increase in car ownerships has also changed domestic holiday taking patterns, giving the tourist an independence and mobility not available through the use of public transport.

2. Tour operation and retail travel, tour operations buy transport accommodation and other services and package them into a single holiday product, which is sold to the customers directly nor more usually through travel agent. Travel agent thus acts as retail out let for holiday product and for individual travel and tourism service. (Inskeep, 1991:69). 
The tour-operating sector offers considerable ranger of product and cater many different markets. Specialist operation provides holiday abroad whilst domestic and Incoming operating primarily direct their activities to send resident abroad.

As it mentions in the previous chapter that the graduate of this institution is expected to be skilful people which are able to handle the tourism industry and especially to the graduate of tourism plan department, they have change to work in the plane like retail and wholesale travel, tour guiding, tourism Information service and MICE agencies as well as their ability to use the specific English terms used for the object of tourism (Depdikbud, 2000).

According to Yoety (2003:39), from the side of function, the terms that usually used at tour and travel field are:

a. The specific terms according to the classification of tour;
1. Deluxe tour
3. Economic class tour.
2. First class of tour
4. Special tour

b. The specific terms according to the type of tour;
1. Independent tour
2. Hosted Tour
3. Escorted Tour
4. Custom tour
5. Excursion tour
6. Optional tour
7. Package tour

c. The specific terms according to the kinds of object of tourism;
1. Cultural object
3. Natural Object
2. Attractive object
4. Historical object

d. The specific terms according to the kind of transportation at destination of tour;

1. Air line

5. Taxi

2. Bus component

6. Cycle hire

3. Ships 7. Coaches

4. Car retail

d. The specific terms according to the global indicators of fares;

1. Eastern hemisphere

4. Polar fares

2. Atlantic pacific fares

5. Western hemisphere

3. South pacific fares

6. Trans atlantics fares

7. North fares

8. Trans-Siberian fares

\section{METHOD AND PROCEDURE}


This chapter describes the method, population and sample, instrument of the research, procedure of collecting data and the technique of data analysis.

A. Research Method

In doing the research, the writer concentrates on obtaining the data that collected through the field research. The method applied in this research was descriptive quantitative. It aims at giving the description of student's achievement in mastering English tourism terms.

\section{B. Population and Sample}

The population of this research was the third year students of SMKP Sandhy Putra I Makassar. It consists of two classes in the 2004/2005 Academic Years. According to their department, there are 30 students of Tourism Plan Department (UJP) and 44 students of Hotel Affairs Accommodation (PH). The total population is 74 students. At the time the writer does the research, $18 \%$ of the population have get field examination, and the total Number of Population whose presents that day was 60 , and the writer take all of them, so the total number of sample was 60, 27 students from UJP and 33 Students PH.

\section{Location of Research}

In doing the research, the writer took a place on SMKP Sandhy Putra I Makassar, which was located on Jln. A.P.Pettarani No. 4. This vocational school was established in 1992 under the supervision of Sandhykara Putra Telkom Bandung Foundation.

\section{Instrument of the Research}

It proposed to measure the achievement of the students in mastering English tourism terms. The tests consisted of two parts. The first part of test deals with the terms which were commonly used at hotel that cover Front Office and Housekeeping Department. This test was directed to the students of Hotel Affairs Accommodation Field. The second part of the test was about the terms used in Tours and travel agencies, which cover Tour and Transportation Department, and it deals with the students of Tourism Plan Field. Each part consists of twenty numbers. In making the test, the writer picked some items up from the textbooks, which in each items deals with the one-tourism terms. The resource books of the test are: English Tourism for Indonesia Spot, edited by Tourism Academy (Akpar) of Sandhy Telkom Bandung 2001; English for housekeeping and Front Office edited by language team of hotel and Tourism Training Institute (BPLP), Makassar 1999; five star English for hotel and Tourism Industry by Chriss Scott edited by Oxford University Press and the Practical English for Tourist, by Sandrina Project, edited by PT.Gramedia, 1992.

The questionnaire was applied to find out the factors influencing the students' achievement in mastering English Tourism Terms. It consists of 16 items which were divided into two parts, namely 15 were closed items and I was open-ended item. The questionnaire was directed to all the sample of this research. 


\section{E. Procedure of Collecting Data}

The research was conducted from 7 to 23 February 2005. It started with getting permission, doing observation field until the data collected. The was collected twice. Firstly, the writer collected the data from tourism plan class and secondly from hotel accommodation class. In each class, the writer distributed the test. Before doing the test, the writer first how to do the tests and asked them to do the test It took 60 minutes. In each class to finish the test. Finally, the writer collected the instrument from respondent.

F. Technique of Data Analysis

The data collected from the objective test were analysed according to following procedure:

1. Scoring the students answer by using the formula:

Students' answer

The total number of item

2. Calculating the score of the students' test.

3. Calculating the mean score of students answer by using the formula:

Where $\mathrm{X}=$ mean score

$$
\begin{gathered}
\mathrm{EX}=\text { the total score } \\
\mathrm{N}=\text { total sample (respondent) }
\end{gathered}
$$

(Gay in Syukur, 2002:20)

The mean score is classified into seven levels as follows:

a. - 10 is classified as excellent

b. $8,6-9,5$ is classified as very good

c. $7,6-8,5$ is classified as good

d. $\quad 6,6-7,5$ is classified as fairly good

e. $\quad 5,6-6,5$ is classified as fair

f. $3,6-5,5$ is classified as poor

g. $\quad-3,5$ is classified as very poor

(Depdikbud in Syukur, 2002:21)

To analyze the result from the questionnaire, the writer firstly tabulated the collected dan from the questionnaire and then into percentage by using the formula:

$\mathbf{P}=\div$ - $\mathrm{x} 100^{\circ} / 0$

Where;

$\mathrm{P}=$ rate percentage

$\mathrm{F}=$ answers from respondent

$\mathrm{N}=$ total sample

(Gay in Syukur, 2002:21) 


\section{FINDING AND DISCUSSION}

This chapter consists of two sections. The first section deals with the finding of the research and the second one deals with discussion.

\section{A. Findings}

The finding of the research deals with the result of the test to know the achievement of the students in mastering English tourism terms. As the writer explains in the previous chapter, the instruments used in this research consist of two parts, namely multiple choice test and questionnaire.

1. The Analysis of Data Collection through Multiple Choice Tests

For the purpose of classifying and tabulating the data into percentage rate, the score for each items of the test was firstly determined. The test consists of items and the score for each items of the test is one per one of correct answers made by students. In order to find out the main score of the students' mastery in English tourism terms, firstly the writer would like to present the raw score in tabulation. Here is the tabulation:

\begin{tabular}{|c|l|c|c|c|}
\hline No & Classification & Score & Frequency & Percentage \\
\hline 1 & Excellent & $9.5-10$ & - & - \\
2 & Very good & $8.5-9.5$ & 1 & $3.7 \%$ \\
3 & Good & $7.5-8.5$ & 6 & $22,2 \%$ \\
4 & Fairly good & $6.6-7.5$ & 16 & $59,3 \%$ \\
5 & Fair & $5.6-6.5$ & 4 & $14,8 \%$ \\
6 & Poor & $3.6-5.5$ & - & - \\
7 & Very poor & $0-3.5$ & - & - \\
\hline
\end{tabular}

The table I show that the highest students' score is 8,5 , there are three students got it while the lowest score is 5,5 and there is only one student get it. Based on the students' classification, the students mean score was classified as "Good".

2. The factor influences the students' achievement in mastering English Tourism Terms.

Based on the analysis of data obtained through the questionnaire as well, the writers indicated some factors influenced the students in mastering English Tourism Terms. Those factors explained as follows.

The first factor is the students basically are motivated in studying English Tourism Terms. Most of the students consider that English Tourism Terms is easy (item 11) while that; the students in generally often practice their English Tourism Terms in 
Communicative way (item 5) especially in the classroom (item 6). The second factor is the facilities that they available from their school, especially the library, safety and warm school area (item 10 and 13). While that most of the students' state that the more they got field practice the more it supported their skill of English Tourism Terms (item 7)

Most of the students said that their teacher' method in teaching Tourism Terms was easy to understood (item 4). Another state that the teacher of SMKP Sandhy Putra 1 Makassar also often explains the Tourism Terms in English and give them assignment about English Tourism Terms (item 2

and 3).

\section{CONCLUSION AND SUGGESTION}

This chapter consisted of two sections. The first section deals with the conclusion of the findings and the other deals with suggestion.

A. Conclusion

Based on the findings and the discussion in the previous chapter, the writer would like to draw some inferences as follows:

1. The students of SMKP Sandhy Putra I Makassar have positive attitude in mastering English Tourism Terms. Most of the students Tourism Plan department reach "Fairly good" score while the students of Hotel Affairs Accommodation were generally "Good" and the total mean score identified that the students of SMKP Sandhy Putra 1 Makassar mastery of English Tourism terms was categories as "Good".

2. The factors influencing the students' achievement in mastering English Tourism Terms are.

a. The students' motivation in studying English Tourism Terms

b. The supporting facilities they've got from their school

c. The teachers' method in teaching English especially English Tourism Terms

d. The frequency of field practice

\section{B. Suggestion}

By observing the result of this research, the writer believed that the achievement of the students of SMKP Sandhy Putra 1 Makassar in mastering English Tourism Terms still could be improved. This can be achieved by doing the following things:

1 To the teacher. The teacher should mountain his/her good method in teaching English Tourism Terms, because the students like it. The teacher had better find another method so the students are not bored. The teacher should give motivation and guidance to the students in studying English Tourism Terms. The teacher should give more exercises and assignment as the follow up of the material taught.

2 To the students. The students should prepare a lot of time to practice the use of English Tourism Terms. The students should be smart in exploit all the facilities given by school. It will be better if the students prepare a lot of time to 
read a book dictionary or even try to explain the tourism spot of brochure by themselves.

\section{REFERENCES}

Akademi Pariwisata Sandhy Putra, 2001. English Tourism for Indonesia Spot. Bandung: Sandhykara Putra Telkom.

Baker Sue, 1994. Principal of Hotel and Front Office Operation. London: Bath Press

Balai Pendiðikan dan Latihan Pariwisata, 1999. English for Housekeeping and Front Office Desk. Makassar: BPLP

Bull Adrian, 1991. The Economic of Travel and Tourism. London: Longman Group, $\mathrm{Ltd}_{\text {. }}$

Burkhart, 1981. Tourism Past, Present and Future London: William Heinemann Ltd.

Cropper Chris and Fletcher John, 1993. Tourism Principle and Practice. London, Heinemann Ltd.

Davis. H, 1986. The Grand Tour. London, Hanish Hamilton.

Departemen Pendidikan dan Kebudayaan, 2000. Kurikulum smk. [online] available: http/www.freeshooting.net/wisata/l ujp.html. (27 February)

Echols John\& Shadily Hasan, 2000 An English —-Indonesia Dictionary. Jakarta PT.Gramedia

Gunn Clare, 1993. A Tourism Planning Third Edition: Taylor and Francis Publisher.

Hasan Salahuddin, 1989. The Necessity of Specific English for Tourist Guides. IKIP FPBS, Ujung Pandang.

Himawati Yulia, 1976. PengantarPariwisata Indonesia. Jakarta. Deparpostel.

Hornby AS, 1995. The Advanced Learner's Dictionary of Current English. Fifth Edition. London: Oxford University Press.

Inskeep Edvsard, 1991. Tourism Planning: An Integrated and Suitable Development Approach. New York: Van Nostrand Reinhold.

Kesrul. M, 2003. Penyelenggaraan Operasi Perjalanan Wisata. Jakarta:Grasindo.

Kodhyat, Rahman, 1998. Kamus Pariwisata dan Perhotelan. Jakarta:Grasindo.

Mansoer, Erwin, 1997. Indonesia South Sulawesi. Published by Department of Tourism, post and Telecommunication South Sulawesi Regional Office Makassar.

Ningsih Winda, 1999. Buku Pintar Wisata Perjalanan Wisata Indonesia. Second Edition, Jakarta Citra Harta Prima

Pattola, Nurdin, 1991. Statistikar IAIN Alauddin Ujung Pandang.

Sandrina, 1992 The Bahasa Inggris Praktis untuk Pariwisata(A Project) Jakarta, PT. Gramedia.

Sulaeman, 2005. Tayangan Pesona Alam dan Budaya Media Televisi dalam Memotivasi Wisata. (jurnal, [online], availablehttpÂw,v.litbang.bupdar.go.id/publikasihtml. (27 February, 2005)

Syukur, Rosita, 2002. The Students Mastery of Pronuntiation of the Third Year Students of MAM Sibatua Pangkep; Thesis IAIN Alauddin Makassar. 